\title{
Induction of mitochondrial dependent apoptosis and cell cycle arrest in human promyelocytic leukemia HL-60 cells by an extract from Dorstenia psilurus: a spice from Cameroon
}

\author{
Constant Anatole Pieme ${ }^{1,2^{*}}$, Santosh Kumar Guru², Pantaleon Ambassa ${ }^{3}$, Suresh Kumar ${ }^{2}$, Bathelemy Ngameni ${ }^{1}$, \\ Jeanne Yonkeu Ngogang ${ }^{1}$, Shashi Bhushan ${ }^{2}$ and Ajit Kumar Saxena ${ }^{2^{*}}$
}

\begin{abstract}
Background: The use of edible plants is an integral part of dietary behavior in the West region of Cameroon. Dorstenia psilurus (Moraceae) is widely used as spice and as medicinal plant for the treatment of several diseases in Cameroon. The aim of this study is to investigate the cytotoxic and apoptotic potential of methanol extract of D. psilurus in human promyelocytic leukemia (HL-60) cells and prostate cancer (PC-3) cells.

Methods: Cytotoxicity of D. psilurus extract was tested in HL-60 and PC-3 cells using 3-(4, 5-dimethylthiazol-2-yl)-2, 5-diphenyltetrazolium bromide (MTT) reduction assay and flow cytometric methods

Results: The methanol extract of D. psilurus have significant in vitro cytotoxic activity in HL-60 cells and PC-3 cells with $I_{50}$ value of $12 \pm 1.54 \mu \mathrm{g} / \mathrm{ml}$ and $18 \pm 0.45 \mu \mathrm{g} / \mathrm{ml}$ respectively after $48 \mathrm{~h}$. The mechanism of antiproliferative activity showed that after $24 \mathrm{~h}$, D. psilurus extract induces apoptosis on HL-60 cells by the generation of reactive oxygen species (ROS) along with concurrent loss of mitochondrial membrane potential, modification in the DNA distribution and enhance of G2/M phase cell cycle.
\end{abstract}

Conclusion: The extract induces apoptosis of HL-60 cells associated with ROS production, loss of mitochondrial membrane potential and apoptotic DNA fragmentation.

Keywords: Dorstenia psilurus, Spice, Apoptosis, HL-60, ROS, Mitochondrial membrane potential

\section{Background}

Spices have served humans as valuable components of seasonings, medicines, and have played a significant role in maintaining human health and improving the quality of human life for thousands of years. There is no doubt that increasing the intake of spices is one of the most effective, convenient and economical ways in which we can fortify ourselves against infectious diseases and related cancers [1]. To date, hundreds of compounds have been identified as potential remedies of cancer, several of which are active ingredients in herbs and spices [2].

\footnotetext{
*Correspondence: apieme@yahoo.fr; aksaxena@iiim.ac.in

${ }^{1}$ Faculty of Medicine and Biomedical Sciences, University of Yaounde I, P.O. BOX 1364, Yaounde, Cameroon

${ }^{2}$ Cancer Pharmacology Division, Indian Institute of Integrative Medicine, Canal Road, Jammu 180001, India

Full list of author information is available at the end of the article
}

The use of herbal remedies based on spices as a kind of complementary and alternative medicine (CAM) is documented in the population especially among cancer patients [3-5]. The spice based herbal medicines and the constituents have been reported to inhibit the proliferation of cancer cells directly. In vitro studies indicate that herbs, spices, and their bioactive components can inhibit, and sometimes induce pathways that regulate cell division, cell proliferation, detoxification, in addition to the inflammatory and immune response $[2,6]$. For instance, ursolic acid, a bioactive component in some herbs and spices, suppressed TNF-induced expression of genes regulated by NF- $\mathrm{kB}$ (cyclin D1, COX-2, and MMP-9) which are involved in tumor initiation, promotion, and metastasis [7]. In Cameroon, several studies 
have been carried on the cytotoxic activity of some spices on different cell lines [8-10].

Dorstenia psilurus (Moraceae) is a plant from widely used in Cameroon, Africa and Madasgascar for different purposes. Plant drugs from this genus have shown a broader acceptability among some indigenous populations $[11,12]$. The roots of $D$. psilurus are used in Cameroon as spices in the traditional meal called "Nkui" and "Nah poh". It is also claimed to preserve health, prevent ageing, to improve the wellbeing and freshness of young mothers after several pregnancies. The chemical composition in terms of macronutrients and micronutrients of roots extract of D. psilurus has been reported [13]. A decoction of leaves of D. psilurus is used in Cameroon to treat rheumatism, snake bites, headache and stomach disorders, arthralgia, cardiovascular disorders, diuretic, tonic, stimulant, analgesic, inflammatory diseases and cancers [14,15]. Phytochemical analysis of root extract of this plant demonstrated the presence of prenylated flavonoids, stearyl-p-coumarate, stearylferulate, benzofuran derivatives, Dorsilurins C, D and E [16] and Dorsilurins (F-K) [17]. The methanol extract of D. psilurus has been reported to have anti-inflammatory property [12]. Some biological activities of root extract of D. psilurus such as the scavenging property on DPPH radical [12], anti-amylase, anti-lipase and antioxidant activities [18] and hypertensive effects, glucosidase inhibitors property [17], antibacterial activity [19] and cytotoxicity activity on MiaPaCa-2 (panceatic), CCRF-CEM, CEM/ADR5000 (leukemia) cells have been demonstrated [8].

However, there are no studies on the cytotoxicity or apoptosis inducing properties of the roots extracts of $D$. psilurus on human promyelocytic leukemia (HL-60) and prostate cancer (PC-3) cell lines. Therefore this research aimed to determine the cytotoxic of the methanol extract of $D$. psilurus (root) on two cell lines (HL-60 and PC-3) and investigate its toxicological mechanism on the most sensitive cells.

\section{Methods}

\section{Plant material and extraction}

The roots of Dorstenia psilurus (D. psilurus) were collected at Komako in the West Region of Cameroon and identified by Mr Victor NANA, of the National Herbarium of Cameroon, in December 2010. A voucher specimen (1649/SRF/CAM) was deposited at the National Herbarium Yaounde, Cameroon. The roots of D. psilurus (DP) were air-dried and ground. The powdered plant material $(150 \mathrm{~g})$ was macerated in $\mathrm{MeOH}(1 \mathrm{l})$ for $24 \mathrm{~h}$ at room temperature and then repeated once. The diluted extract was concentrated under reduced pressure to afford $40 \mathrm{~g}$ of a dark residue.

\section{Cell culture}

Human promyelocytic leukemia (HL-60 cells) and prostate cancer (PC-3 cells) were obtained from European Collection of Cells Culture (ECCC), Sigma Aldrich, India. They were grown in RPMI-1640 medium containing 10\% Foetal bovine serum (FBS), penicillin $(100 \mathrm{IU} / \mathrm{ml})$ and streptomycin $(100 \mu \mathrm{g} / \mathrm{ml}$ medium). The cells were culture in the incubator (Thermocom Electron Corporation, USA) at $37^{\circ} \mathrm{C}, 5 \%$ $\mathrm{CO}_{2} ; 98 \%$ humidity. Cells were used for different assays during logarithmic growth phase while the untreated control cultures received only the vehicle (DMSO $<0.1 \%$ ).

\section{Cells viability and treatments}

The human promyelocytic leukemia (HL-60 cells) and prostate cancer (PC-3 cells) were seeded in different 96 well plates containing $15 \times 10^{3}$ and $6 \times 10^{3}$ cells $/ 100 \mu \mathrm{l} /$ well, respectively. The cultured cells were then treated the same (triplicate wells per condition) by the addition of $100 \mu \mathrm{l}$ of serial dilutions of the DP extract dissolved in DMSO to give a final concentration of 30,10 and $1 \mu \mathrm{g} / \mathrm{ml}$. For PC-3, the extract was added after $24 \mathrm{~h}$ of incubation. In addition, the DMSO alone was added to another set of cells as the solvent control (DMSO $<0.1 \%$ ). The cells were then incubated for another $48 \mathrm{~h}$ prior to the addition of $20 \mu \mathrm{l}$ of $2.5 \mathrm{mg} / \mathrm{ml}$ solution of 3-(4, 5-dimethylthiazol-2-yl)-2, 5-diphenyltetrazolium bromide (MTT) into each well. The incubation was continued for another $3 \mathrm{~h}$ before the media was removed. A mixture of DMSO $(150 \mu \mathrm{l})$ was added to each well and mixed to ensure dissolving of the crystal formazan before the absorbance at $570 \mathrm{~nm}$ was measured. Three replications of each experiment were performed and fifty percent of inhibitory concentration $\left(\mathrm{IC}_{50}\right)$ of each extract was calculated.

\section{DNA content and cell cycle phase distribution}

HL-60 cells $\left(1 \times 10^{6}\right.$ cells $/ 2 \mathrm{ml} /$ well $)$ were treated with DP at $20,50,100 \mu \mathrm{g} / \mathrm{ml}$ for $24 \mathrm{~h}$. They were harvested and washed with $1 \mathrm{ml}$ of PBS, then centrifuged $400 \mathrm{~g}$ for $5 \mathrm{~min}$ at $4^{\circ} \mathrm{C}$. The pellet was suspended in $100 \mu \mathrm{l}$ of PBS and $900 \mu \mathrm{l}$ of hypertonic buffer (PI- $25 \mu \mathrm{g} / \mathrm{ml}$, RNAase-40 $\mu \mathrm{g} / \mathrm{ml}$, sodium citrate- $0.1 \%$ and Triton- $100 \mathrm{X}-0.03 \%$ ) and incubated at $37^{\circ} \mathrm{C}$ in dark for $20 \mathrm{~min}$. Finally, cells were analyzed immediately on flow cytometer FACSCalibur (Becton Dickinson, USA). The data were collected in list mode on 10,000 events and illustrated in a histogram, where the number of cells (counts) is plotted against the relative fluorescence intensity of PI (FL-2; $\lambda$ em: $585 \mathrm{~nm}$; red fluorescence). The resulting DNA distributions were analyzed by Modfit (Verity Software House Inc., Topsham, ME) for the proportions of cells in $G_{0}-G_{1}, S$ - phase, and $\mathrm{G}_{2}-\mathrm{M}$ phases of the cell cycle [20].

\section{Hoechst 33258 staining of cells for nuclear morphology} HL-60 cells $\left(2 \times 10^{6}\right.$ cells $/ 3 \mathrm{ml} /$ well $)$ were treated with DP extract at different concentration of extract for $24 \mathrm{~h}$. They were collected, centrifuged at $400 \mathrm{~g}$ and washed once with PBS. A solution of Hoechst (Hoechst, $10 \mu \mathrm{g} / \mathrm{ml}$; 
citric $10 \mathrm{mM} ; \mathrm{Na}_{2} \mathrm{HPO}_{4} \quad 0.45 \mathrm{M}$; Tween-20 0.05\%) was added in each tube and kept in the dark at room temperature for $30 \mathrm{~min}$. The mixture was then washed once with PBS and the pellet resuspended in $100 \mu \mathrm{l}$ of PBS/glycerol (1:1). The solution $(10 \mu \mathrm{l})$ was poured into the slide and observed for nuclear morphology alterations under fluorescence microscope (Olympus X 70, magnification $20 \mathrm{X}$ ).

\section{Mitochondrial membrane potential (MMP) assay}

HL-60 cells $\left(1 \times 10^{6}\right.$ cells $/ 2 \mathrm{ml} /$ well $)$ were treated with DP extract at different concentrations for $24 \mathrm{~h}$. Thirty minutes before the end of the experiment, the cell culture was treated with Rhodamine-123 (200nM) and keep in the dark for $30 \mathrm{mn}$. Cells were then collected, centrifuged ( $400 \mathrm{~g} ; 4^{\circ} \mathrm{C} ; 5 \mathrm{~min}$ ), the pellet was washed with $1 \mathrm{ml}$ of PBS and centrifuged as mentioned earlier. The fluorescence intensity of 10,000 events was analyzed in FL-1 channel on BD FACSCalibur (Becton Dickinson, USA) flow cytometer. The decrease in fluorescence intensity because of mitochondrial membrane potential loss was analyzed in FL-1 channel and the change of in potential membrane $(\Delta \psi \mathrm{m})$ was assessed by comparing fluorescence.

\section{Reactive oxygen species (ROS) assay}

ROS production was monitored by flow cytometry using 2', 7'-dichlorodihydrofluorescin diacetate $\left(\mathrm{DCFH}_{2}-\mathrm{DA}\right)$. This dye is a stable non polar compound that readily diffuses into cells and is hydrolyzed by intracellular esterase to yield 2,7'-dichloro dihydrofluorescin (DCFH), which is trapped within the cells. Hydrogen peroxide or low molecular weight peroxides produced by the cells oxidize DCFH to the highly fluorescent compound 2,7'-dichlorofluorescein (DCF). Thus, the fluorescence intensity is proportional to the amount of hydrogen peroxide produced by the cells. Briefly, HL-60 cells $\left(1 \times 10^{6}\right.$ cells $/ 2 \mathrm{ml} /$ well) were treated with DP at different concentration for $24 \mathrm{~h}$. Thirty minutes before the end of the experiment, the cell culture was treated with $\mathrm{DCFH}_{2}$-DA $(50 \mu \mathrm{M})$ and keep in the dark. Cells were then collected, centrifuged ( $200 \mathrm{~g} ; 4^{\circ} \mathrm{C} ; 5 \mathrm{~min}$ ) and the pellet was washed with $1 \mathrm{ml}$ of PBS and centrifuged as mentioned earlier. The pellet was suspended in $500 \mu \mathrm{l}$ of PBS and the fluorescence was assessed by comparing two fluorescence emission $480 \mathrm{~nm} / 530 \mathrm{~nm}$ using a flow-cytometer (BD-LSR).

\section{Statistical analysis}

The viability experiments were done in triplicates and each data point represents the average of at least 3 independent experiments. The data was expressed as mean \pm SD. In order to carry out statistical analysis, the data was analyzed using SPSS (Version 11.5; SPSS Inc.)) and M.S.
Office, Excel software. One way analysis of variance technique was applied to observe the significance between the groups. The post hoc test Duncan's multiple range test was performed to know the significant difference among the groups. Entire statistical analysis was carried out at $\mathrm{p}<0.05$.

\section{Results}

In this study, the human promyelocytic leukemia cell line, (HL-60), was used to investigate the capability of the methanol extract of DP to induce apoptosis and elaborate its molecular mechanism. After extraction, the yield of DP extract was $26.6 \%$.

\section{Effects of DP extracts on the proliferation of HL-60 and PC-3 cells}

Using a conventional tatrazolium-based colorimetric cell proliferation assay, we screened the antiproliferative activity of DP at $100 \mu \mathrm{g} / \mathrm{ml}$ for $48 \mathrm{~h}$. The results demonstrated that these extracts reduced the cell viability between 6.25 and $6.87 \%$ depending on the cells. The viability of both cells decrease from $60.4 \pm 2.84 \%$ and $65.51 \pm 6.70 \%$ respectively for HL-60 and PC-3 at $1 \mu \mathrm{g} / \mathrm{ml}$ to $6.25 \pm 2.31 \%$ and $6.87 \pm 3.15 \%$ at $100 \mu \mathrm{g} / \mathrm{ml}$ after treatment. Further, the cytotoxicity effects of this extract were performed at different concentrations $(1-100 \mu \mathrm{g} / \mathrm{ml})$ as shown in the Figure 1. After $48 \mathrm{~h}$, the extract of DP demonstrated a significant reduction of cell viability on both cell lines in a dose dependent manner. The fifty percent inhibitory concentrations $\left(\mathrm{IC}_{50}\right)$ were $12 \pm$ $1.54 \mu \mathrm{g} / \mathrm{ml}$ and $18 \pm 0.49 \mu \mathrm{g} / \mathrm{ml}$ respectively with HL-60 and PC-3 (Table 1). This result confirmed that DP has significant cytotoxicity property on HL-60 cells and this cell line was chosen for the other experiments.

\section{Morphological changes of apoptotic treated HL-60 cells with DP extract}

Nucleosomal DNA fragmentation is the result of activation of endogenous endonuclease. To investigate whether the DP extract can induce apoptosis and nuclear modification on HL-60 cells after $24 \mathrm{~h}$ of treatment, the Hoechst 33258 staining was also carried out at different concentrations $(20,50$ and $100 \mu \mathrm{g} / \mathrm{ml})$. It is a membrane-permeable blue fluorescent dye which stained cell nucleus. The results show that the untreated HL-60 cells present the uniformly light blue nuclei under fluorescence microscope demonstrating that the cells are in healthy conditions (Figure 2A). DP-treated HL-60 cells exhibited a bright blue color (Figure 2) confirming the dead of cells. DP-treated HL-60 cells showed condensed and marked fragmented nuclei in a time-dependent manner (Figures 2C \& 2D). At $100 \mu \mathrm{g} / \mathrm{ml}$, most of the cells go through apoptosis; and the increase of the apoptotic corps was noted (Figure 2E). 


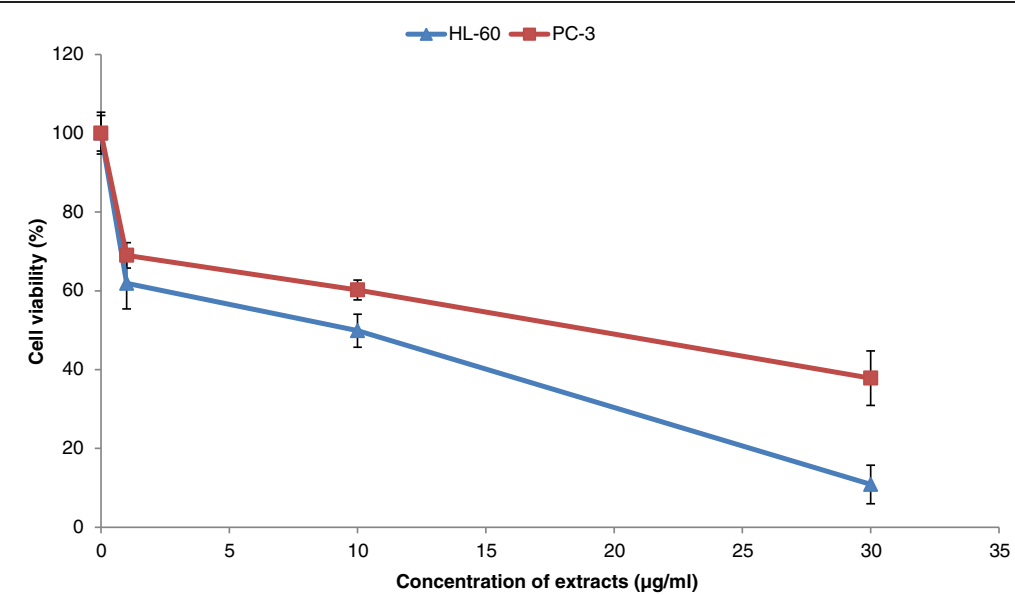

Figure 1 Viability of PC-3 and HL-60 cells after 48 h treatment with DP extract $(n=3)$.

The results indicated that DP extract induces the fragmentation of DNA of death HL-60 cells.

\section{Reactive specific oxygen (ROS) production by treated HL-60 cells with DP extract}

ROS are generated in and around mitochondria and are regarded as the byproducts of normal cellular oxidative processes. As many anticancer drugs and DNA damagecausing agents activate the apoptotic pathway through ROS generation, the possibility that ROS elevation is a key step in DP-induced apoptosis was assessed using $\mathrm{DCFH}_{2}-$ DA. The results showed that the intracellular ROS production of treated HL-60 cells increased 7.54 and 9.32 folds respectively at 20 and $50 \mu \mathrm{g} / \mathrm{ml}$ compare to the control (Figure 3). However the ROS production at $100 \mu \mathrm{g} / \mathrm{ml}$ was almost equal to the control the death of cells.

\section{Effect of DP extract on the mitochondrial membrane potential of $\mathrm{HL}-60$ cells}

Mitochondria play important role in the propagation of apoptosis and they are responsible for $90 \%$ of the energy needed for cells function. The disruption of mitochondrial integrity is one of the early events leading to apoptosis. To assess whether DP extract affects the function of mitochondria, the potential changes in mitochondrial membrane were analyzed by employing Rodamine-123, a dye which indicates the loss of mitochondrial membrane potential.

Table 1 Cells viability and fifty percent inhibition of HL-60 and PC-3 cells after 48 h

\begin{tabular}{lll}
\hline Cell lines & Viability (\%) & $\mathbf{I C}_{\mathbf{5 0}}$ \\
& $\mathbf{1 0 0} \boldsymbol{\mu \mathbf { g } / \mathbf { m l }}$ & $\mathbf{( \mu \mathbf { g } / \mathbf { m l } )}$ \\
\hline $\mathrm{HL}-60$ & $6.25 \pm 2.31$ & $12 \pm 1.5$ \\
$\mathrm{PC}-3$ & $6.87 \pm 3.15$ & $18 \pm 0.49$ \\
\hline
\end{tabular}

Results are represented as mean $\pm S D, n=3$.
The results showed that the untreated HL-60 cells retained $90.89 \%$ of fluorescence. After $24 \mathrm{~h}$ of treatment cells with DP extract, the decline of fluorescence was enhanced in a concentration dependent manner from $23.03 \%$ at $20 \mu \mathrm{g} / \mathrm{ml}$ to $88.13 \%$ at $100 \mu \mathrm{g} / \mathrm{ml}$ (Figure 4 ). This result confirmed that DP extract induced apoptosis through the disruption of mitochondria membrane potential. This finding supports the view that alteration of mitochondria functions play a major role in the apoptosis in particular in cell death induced by chemotherapy [21].

\section{Effect of DP extract on DNA content and cell cycle of HL-60 cells}

The flow cytometric analysis of propiduim Iodide (PI)stained was used to investigate the effect of DP extract on cell cycle progression on HL-60 cells. The results showed that the normal distribution cell cycle in the control. After treatment with extract at different concentration, the accumulation of cells was found in apoptotic phase (subG1) with significant modification of G2/M and $\mathrm{S}$ phases at the concentration of 20 and $50 \mu \mathrm{g} / \mathrm{ml}$ (Figure 5). Cells treated with $100 \mu \mathrm{g} / \mathrm{ml}$ of extract resulted to extensive accumulation of subG1 phase and loss of normal profile of the cell cycle.

The results demonstrated that DP extract induced apoptosis on HL-60 cells through cell cycle arrest. The proportion of cells in subG1 and S phases increased whereas cells in $\mathrm{G} 1 /$ Go phase decreased significantly in a concentration dependent manner compare to the control (Figure 6). The level of variation is between $2.87-107.43$ and $2.52-100.68$ fold respectively for subG1 and G1/Go.

\section{Discussion}

Recently, important attention has been focused on identifying natural substances capable of inhibiting or retarding the process of different stages of carcinogenesis. Anticancer drugs from natural sources having minimum side effects, 

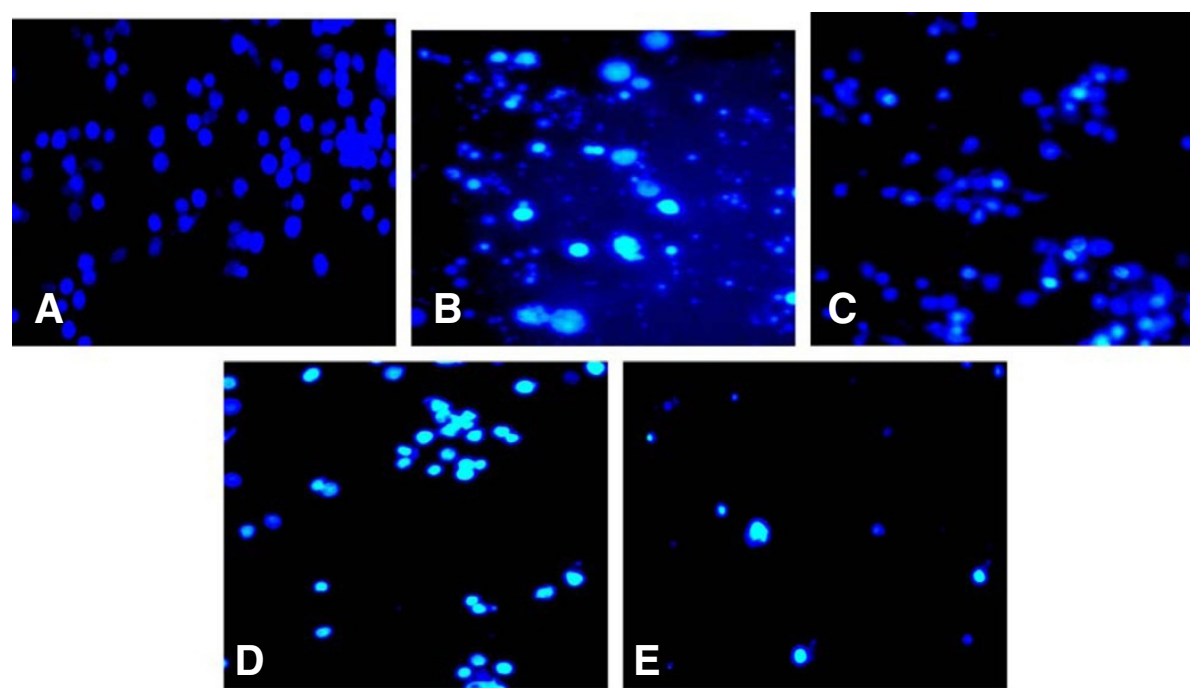

Figure 2 Effect of DP extract on nuclear morphological changes of HL-60 cells after $24 \mathrm{~h}$ and observation under fluorescence microscope (Olympus, Tokoy, Japan; magnification - 200). (A): control; (B): Camptotecin (2 $\mu \mathrm{M}) ;(\mathrm{C}): 20 \mu \mathrm{g} / \mathrm{ml}$; (D): $50 \mu \mathrm{g} / \mathrm{ml}$; (E): $100 \mu \mathrm{g} / \mathrm{ml}$.

inducing apoptosis, and targeting specific cytotoxicity to the cancer cells are the drugs of choice [22]. Finding novel natural compounds with low toxicity and high selectivity of killing cancer cells is an important area in cancer research. Anticancer drugs act by interfering with cell proliferation or, in most cases, by inducing programmed cell death, known as apoptosis [23]. Our studies revealed that DP extract demonstrated cytotoxicity activity on HL-60 and PC-3 cell lines with $\mathrm{IC}_{50}$ of 12 and $18 \mu \mathrm{g} / \mathrm{ml}$ respectively. These values are lower than $20 \mu \mathrm{g} / \mathrm{ml}$ (Figure 1). According to the US NCI plant screening program, a crude extract is considered to have

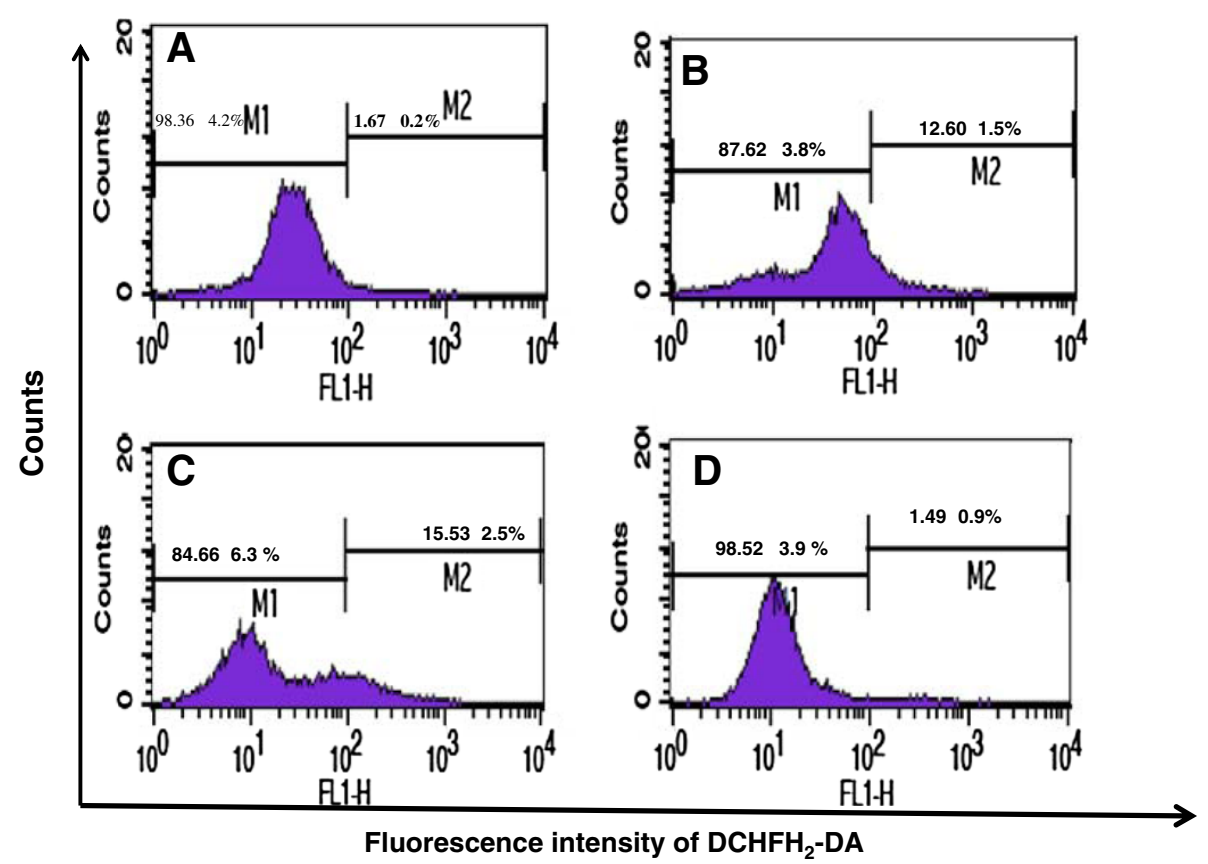

Figure 3 Effects of extract DP on ROS production on HL-60 cells; Cells were treated with extract for $24 \mathrm{~h}$ followed by staining with $\mathrm{DCHFH}_{2}$-DA $(5 \mu \mathrm{M})$, incubated for $30 \mathrm{~min}$ and the fluorescence in the cells was immediately analyzed using flow cytometry. Data are presented the fluorescence intensity: (A): control; (B): $20 \mu \mathrm{g} / \mathrm{ml}$; (C): $50 \mu \mathrm{g} / \mathrm{ml}$; (D): $100 \mu \mathrm{g} / \mathrm{ml}$. 


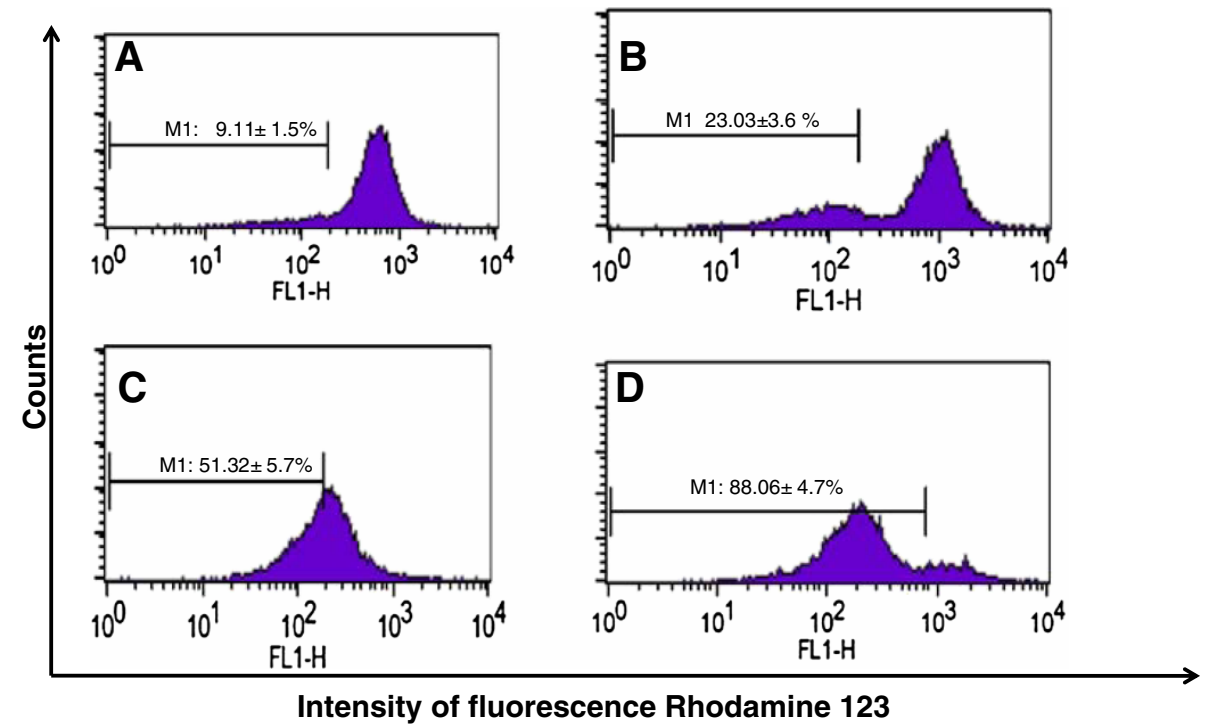

Figure 4 Effects of DP on the integrity of mitochondrial membrane of HL-60 cells after $\mathbf{2 4} \mathbf{~ h}$. Data are presented the fluorescence intensity: (A): control; (B): $20 \mu \mathrm{g} / \mathrm{ml}$; (C): $50 \mu \mathrm{g} / \mathrm{ml}$; (D): $100 \mu \mathrm{g} / \mathrm{ml}$.

in vitro cytotoxic activity, if the $\mathrm{IC}_{50}$ value following incubation between 48 and $72 \mathrm{~h}$ is less than $20 \mu \mathrm{g} / \mathrm{ml}$ [24]. Previous studies have indicated that root extract of $D P$ has inhibitory activity against various cancer cell lines [12]. Cytotoxicity of DP extract arises its ability to interact with proteins, DNA via several functional groups by ionic interaction [25] or by DNA intercalation [26]. Literatures data on the cytotoxicity and apoptosis properties of DP extract are scarce. Our study is the baseline study on cytotoxicity and the apoptosis inducing properties of DP extracts on HL-60 cells. Apoptosis provides a number of clues with respect to effective anticancer therapy, and many chemotherapeutic agents reportedly to exert their antitumor effects by inducing apoptosis in cancer cells. Three apoptosis parameters of the intrinsic mediated apoptosis pathway have been investigated in our study with the HL-60 cells (i) apoptosis mediated by cell cycle arrest through the fixation to the receptors ; (ii) apoptosis mediated by mitochondria-involved signaling; (iii) the reactive oxygen species (ROS) induced apoptosis.

Cell cycle arrest is one of main the targets of many anticancer drugs such as camptothecin, doxorubicin, cisplatin, 5 -fluorouracil. It has been shown that the ability of molecules/drugs to arrest cell cycle in G2/M or S phase was related to their sensitivity and increased with cell resistance [27]. Our results showed the increase of apoptotic cells, G2/M and $M$ phase in a concentration dependent manner when the concentration of extract was raised compare with the control (Figure 6). This result showed that extract could act at all the stages of HL-60 cell cycle in a concentration-dependent and can be ranged among the cell cycle with non-specific agents. Several studies have reported that apoptosis involves a disruption of mitochondrial membrane integrity is decisive for the cell death process [28-30] and the depolarization of mitochondrial membrane potential is a characteristic feature of apoptosis. The evaluation of the effects of DP extract on the mitochondrial membrane potential $(\Delta \psi \mathrm{m})$ demonstrated the increase of loss of intensity of fluorescence respectively $2.52 \% ; 5.62 \%$ and $9.66 \%$ fold at 20,50 and $100 \mu \mathrm{g} / \mathrm{ml}$. The decline of the fluorescence confirmed the death of the treated-HL-60 cells through the depolarization of their mitochondrial membrane potential. The finding confirmed that DP extract induces apoptosis of HL-60 through the disruption of mitochondrial membrane potential. This result supports the concepts that mitochondria are one of the most important organelles in cells which play critical roles in the mitochondrial apoptosis signal transduction pathway [22]. The loss of membrane potential is an early event in mitochondrial-mediated apoptosis [31]. After the reduction of membrane potential and the release of mitochondrial cytochrome $\mathrm{C}$, a critical step is the formation of apoptosomes.

Identification of some features characteristic of apoptotic morphology such as degradation of DNA and apoptotic bodies (Figures 2D \& 2E) confirm the specific cleavage of DNA at sites between nucleosomes and the formation of a 'ladder' an indicator of apoptosis by DP extract [32]. The relationships between the mitochondrial dysfunctions observed during aging ROS production is still debated [33]. A disruption of mitochondrial membrane potential was observed in HL-60 cells exposed to oxidative stress provoked by duocarmycin A [34] and the elevation of the 


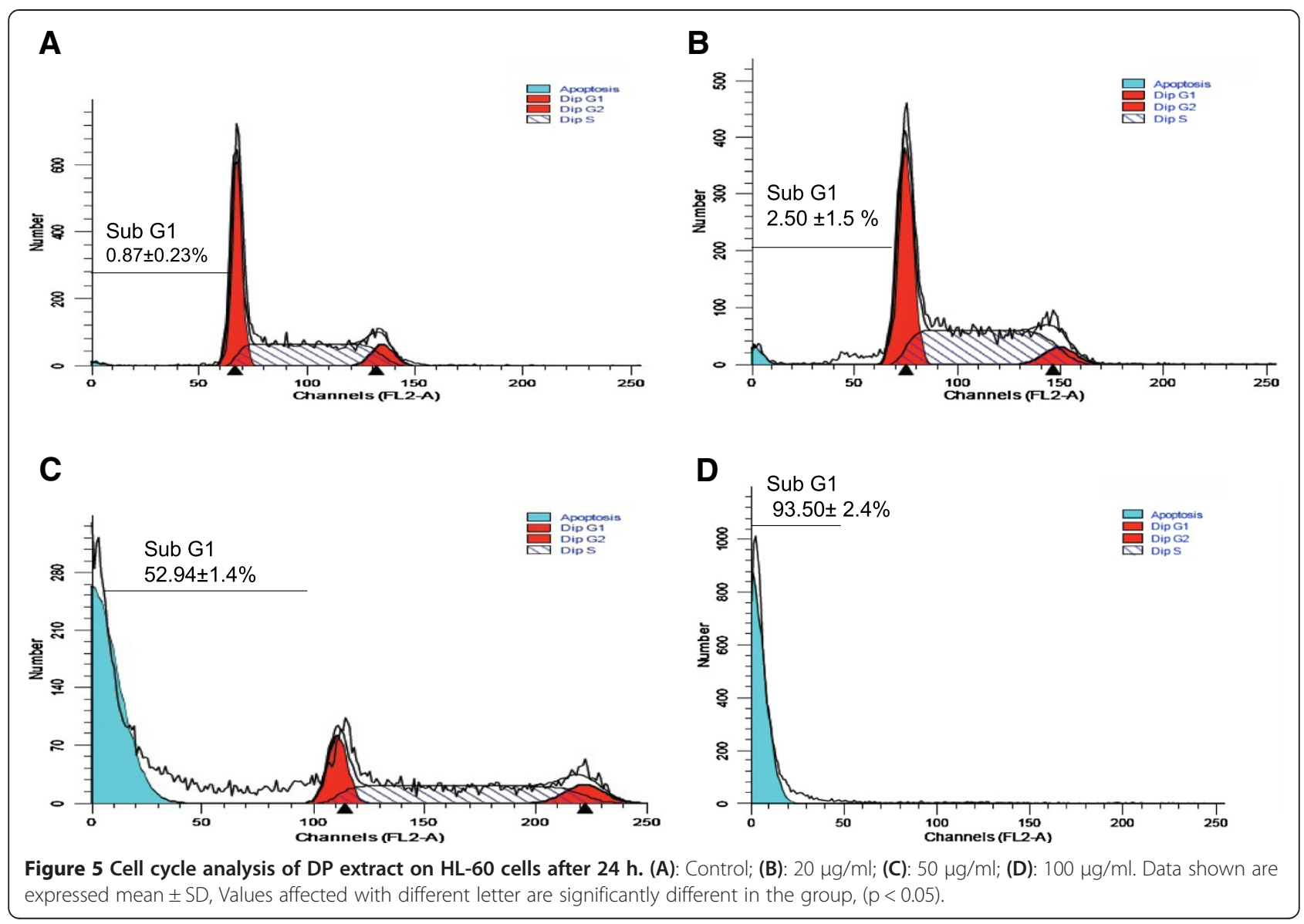

cellular ROS production can promote apoptosis [35]. Over production of ROS results in oxidative damage including lipid peroxidation, protein oxidation and DNA damage. A number of studies have shown that the phytochemicals involved in ROS production can selectively kill the cancer cells by raising the level of ROS above a toxic threshold
[30,36,37]. HL-60 treated cells increase ROS production for almost 7.54 and 9.33 fold at 20 and $50 \mu \mathrm{g} / \mathrm{ml}$ respectively. These results confirmed that ROS were crucial in the induction of apoptosis and acted as upstream signaling molecules to initiate cell death. Besides apoptosis, the reduction in cell viability was further due to an arrest in the

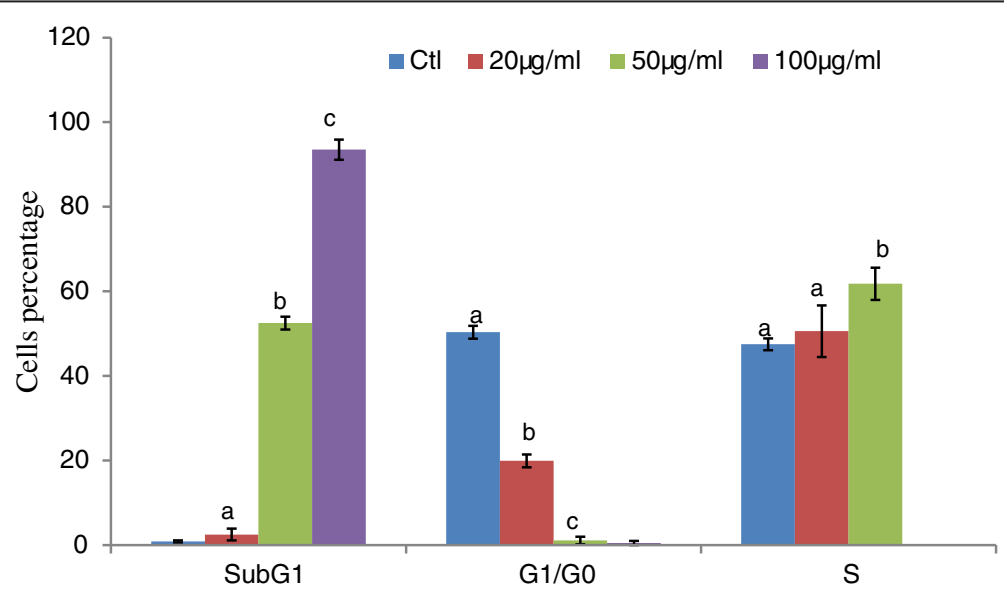

Figure 6 Effect of DP extract on cell distribution after $\mathbf{2 4}$ h. Data represents mean \pm S.D. of three experiments. $p<0.001$ was considered significantly different in comparison with the control. 
G2/M phase, the concentration dependent decline of mitochondrial membrane potential and increased of ROS production on HL-60 cells.

Identification of the phytochemicals compounds responsible of apoptosis may have important on anticarcinogenic activities [38]. Studies have been reported the presence of several bioactives compounds in DP extracts such as flavonoids, furano-coumarins, phenylated flavonoids $[16,17]$. Several studies demonstrated the mechanistic induction of apoptosis of different main groups of compounds present in DP extracts such as phenylated flavonoids [39,40] benzofuran [41]. Reports showed that plant-derived phenylated flavonoids and benzofuran, are cytostatic against various human cancer cell lines and induces apoptosis [42]. Therefore, our data suggested the possibility that DP might penetrate into cells and directly target mitochondria to increase membrane permeability and decrease $(\Delta \psi \mathrm{m})$ accompanied by ROS production.

\section{Conclusion}

The present study indicates that DP extract can effectively inhibit proliferation of HL-60 and PC-3 cells. The apoptosis induction of HL-60 cells is accompanied by the production of ROS, the perturbation of mitochondrial membrane function.

\section{Abbreviations}

MTT: 3-(4,5-dimethylthiazole-2-yl)-2,5-diphenyltetrazolium bromide; PI: Propidium iodide; Rh-123: Rhodamine- 123; DCFH $2-D A: 2^{\prime}, 7^{\prime}$ dichlorodihydrofluorescin diacetate.

\section{Competing interests}

The authors declare that they have no competing interests.

\section{Authors' contribution}

PCA. Design, perform the study and write the manuscript; SG and SK help to perform the study; AP and NB collected the plant and carried out the extraction; SB and NYJ provided technical support and correct the manuscript, AKS provided all the reagent and chemical. All authors read and approved the final manuscript.

\section{Acknowledgements}

The authors wish to thank the Federation of Indian Chambers of Commerce and Industry (FICCI), who provided scholarship to Dr PIEME C.A. through CV Raman programme to conduct this research in the Indian Institute of Integrative Medicine (CSIR).

\section{Author details}

${ }^{1}$ Faculty of Medicine and Biomedical Sciences, University of Yaounde I, P.O. BOX 1364, Yaounde, Cameroon. ${ }^{2}$ Cancer Pharmacology Division, Indian Institute of Integrative Medicine, Canal Road, Jammu 180001, India. ${ }^{3}$ Faculty of Science, University of Yaounde I, P.O. BOX 812, Yaounde, Cameroon.

Received: 20 May 2013 Accepted: 30 August 2013

Published: 10 September 2013

\section{References}

1. Steinmetz KA, Potter JD: Vegetables, fruit, and cancer prevention: a review. J Am Dietet Assoc 1996, 96:1027-39.

2. Kaefer CM, Milner JA: The role of herbs and spices in Cancer prevention. J Nutr Biochem 2008, 19(6):347-361.
3. Xu W, Towers AD, Li P, Collet JP: Traditional Chinese Medicine in cancer care: perspectives and experiences of patients and professionals in China. Eur J Cancer Care 2006, 15:397-403.

4. Boon HS, Olatunde F, Zick SM: Trends in complementary /alternative medicine use by breast cancer survivors: comparing survey data from 1998 and 2005. BMC Womens Health 2007, 7:4.

5. Dwivedi V, Shrivastava R, Hussain S, Ganguly C, Bharadwa M: Cytotoxic potential of Indian spices (extracts) against esophageal Squamous carcinoma cells. Asian Pacific J Cancer Prev 2011, 12:2069-2073.

6. Hollman PC, Katan MB: Dietary flavonoids: intake, health effects and bioavailability. Food Chem Toxicol 1999, 37(910):937-42.

7. Shishodia S, Majumdar S, Banerjee S, Aggarwal BB: Ursolic acid inhibits nuclear factor-kappa B activation induced by carcinogenic agents through suppression of IkappaBalpha kinase and p65 phosphorylation: correlation with down-regulation of cyclooxygenase 2, matrix metalloproteinase 9, and cyclin D1. Cancer Res 2003, 63(15):4375-4383.

8. Kuete V, Wabo KH, Eyong KO, Feussi MT, Wiench B, Krusche B, Tane P, Folefock GN, Efferth T: Anticancer activities of six selected natural compounds of some Cameroonian medicinal plants. PLOS ONE 2011, 6(8):e21762. doi:10.1371/ journal.pone.0021762.

9. Choumessi AT, Danel M, Chassaing S, Truchet I, Penlap BV, Pieme CA, Asonganyi T, Ducommun B, Valette A: Characterization of the antiproliferative activity of Xylopia aethiopica. Cell Div 2012, 7:1-8.

10. Choumessi AT, Loureiro R, Silva AM, Moreira AC, Pieme CA, Tazoacha A, Oliveira PJ, Penlap BV: Toxicity evaluation of some traditional African spices on breast cancer cells and isolated rat hepatic mitochondria. Food Chem Toxicol 2012, 50(11):4199-4208.

11. Abegaz BM, Ngadju BT, Dongo E, Bezabih MT: Chemistry of the genus Dorstenia. Cur Org chem 2000, 4(10):1079-1090.

12. Kansci G, Dongo E, Genot C: 2,2-Diphenyl-1-picrylhydrazyl (DPPH) test demonstrates antiradical activity of Dorstenia psilurus and Dorstenia ciliate plant extracts. Nahrung/Food 2003, 47(6):434-437.

13. Tchiégang CM, Bougueng PD: Chemical composition of spices used for the preparation of Nah poh and Nkui two dishes from west Cameroon. Tropicultura 2005, 23(4):193-200.

14. Ruppelt BM, Pereira EF, Goncalves LC, Pereira NA: Pharmacological screening of plants recommended by folk medicine as anti-snake venom I. Analgesic and anti-inflammatory activities. Mem do Instit Oswaldo Cruz 1991, 86:203-205.

15. Abegaz BM, Ngadjui TB: Chemistry and marketed plants from Eastern and Southern Africa. Niger J Nat Prod Med 1999, 3:19-25.

16. Ngadjui BT, Tabopda TK, Dongo E, Kapche GWF, Sandor P, Abegaz BM: Dorsilurins $C, D$ and $E$, three prenylated flavonoids from the roots of Dorstenia psilurus. Phytochem 1999, 52(4):731-735.

17. Tabopda TK, Ngoupayo J, Awoussong KP, Mitaine-Offer AC, Muhammad SA, Ngadjui BT, Lacaille-Dubois MA: Triprenylated flavonoids from Dorstenia psilurus and their a-Glucosidase Inhibition Properties. J Nat Prod 2008, 71:2068-2072.

18. Etoundi CB, Kuaté D, Ngondi JL, Oben J: Anti-amylase, anti-lipase and antioxidant effects of aqueous extracts of some Cameroonian spices. J Nat Prod 2010, 3:165-17.

19. Tabuti JR, Kukunda CB, Waako PJ: Medicinal plants used by traditional medicine practitioners in the treatment of tuberculosis and related ailments in Uganda. J Ethnopharmacol 2010, 127:130-136.

20. Voukeng IK, Kuete V, Dzoyem JP, Fankam AG, Noumedem JA, Kuiate JR, Pages JM: Antibacterial and antibiotic-potentiation activities of the methanol extract of some Cameroonian spices against Gram-negative multi-drug resistant Phenotypes. BMC Res Notes 2012, 5(299):1-10.

21. Bhushan S, Kumar A, Malik F, Andotra SS, Sethi VK, Kaur IP, Taneja SC, Qazi GN, Singh J: A triterpenediol from Boswellia serrata induces apoptosis through both the intrinsic and extrinsic apoptotic pathways in human leukemia HL-60 cells. Apoptosis 2007, 12:1911-1926.

22. Kug CK, Jin SK, Jung KS, In Gyu K: Enhance induction of mitochondrial damage and apoptosis in leukemia HL-60 cells by the Ganoderma lucidum and Duchesnea chysantha extracts. Cancer letter 2007, 246:210-217.

23. Nahata A, Saxena A, Nitasha S, Saxena AK, Kumar DV: Sphaeranthus indicus induces Apoptosis through mitochondrial-dependent pathway in $\mathrm{HL}-60$ cells and exerts cytotoxic potential on several human cancer cell lines. Interg Cancer Therap 2012:1-12. 10.1177/1534735412451997.

24. Vieira MS, Castello B, Tavares JF, Silva SM, Barbosa FMJ, Anazetti CM, Frungillo L, Haun M, Melo-Diniz MFF, Melo SP: Xylodiol from Xylopia 
langsdorfiana induces apoptosis in HL60 cells. Braz J Pharmacog 2011, 21(6):1035-1042

25. Boik J: Natural compounds in cancer therapy. LLC Minnesota: Oregon Medical Press; 2001.

26. Vrba J, Doležel P, Vičar J, Modrianský M, Ulrichová J: Chelerytrine and dihydrochelerythrine induce G1 phase arrest and bimodal cell death in human leukemia HL-60 cells. Toxicol Vitro 2008, 22:1008-1017.

27. Kaminskyy VO, Lootsik MD, Stoika RS: Correlation of the cytotoxicity activity of four different alkaloids from Chelidonium majus (greater celandine) with DNA intercalating properties and ability to induce breaks in DNA of MK/Ly murine lymphoma cells. Central Eur J Biol 2006, 1:2-15.

28. Dong XC, Bin Q, Zhi-Qiang G, Ying JY: Comparison of burst of reactive oxygen species and activation of caspase- 3 in apoptosis of K562 and HL-60 cells induced by docetaxel. Cancer Lett 2012, 214:103-113.

29. Ying-Tang H, Yi-Hsuan H, Tzhy-Chyuan H, Bonnie SP, Yeuk CL, Min-Hsiung P. Apoptosis-inducing active components from Corbicula fluminea through activation of caspase- 2 and production of reactive oxygen species in human leukemia HL-60 cells. Food Chem Toxicol 2006, 44:1261-1272.

30. Nunes C, Barbosa MRL, Laranjinha J: Nitric oxide and DOPAC-induced cell death: From GSH depletion to mitochondrial energy crisis. Mol Cell Neurosci 2011, 48:94-103.

31. Muhammad K, Chuan D, Azhar R, Fei Y, Ting L, Hongwen G, Rong G, Lili Z, Kun $Z$, Xuedong F, Tonghui M: Isoalantolactone induces reactive oxygen species mediated apoptosis in pancreatic carcinoma PANC-1 cells. Int J Biol Sci 2012, 8(4):533-547.

32. Stepanek O, Brdicka T, Angelisova P, Horvath O, Spicka J, Stockbauer P, Man $P$, Horejsi V: Interaction of Late Apoptotic and Necrotic Cells with Vitronectin. Plos One 2011, 6(5):e19243. doi:10.1371/journal.pone.0019243.

33. Potter $\mathrm{CL}$, Hanson PJ: Exogenous nitric oxide inhibits apoptosis in guinea pig gastric mucous cells. Gut 2000, 46:156-163.

34. Marchi S, Giorgi C, Suski MJ, Agnoletto C, Bononi A, Bonora M, De Marchi E, Missiroli S, Patergnani S, Poletti F, Rimessi A, Duszynski J, Wieckowski MR, Pinton P: Mitochondria-ROS crosstalk in the control of cell death and aging. J Signal Transd 2007:1-17. ID 329635 doi:10.1155/2012/329635.

35. Rosgalska A, Koceva CA, Zofia J: Aclarubicin-induced ROS generation and collapse of mitochondrial membrane potential in human cancer cell lines. Chem Biol Inter 2007, 176:58-70.

36. Nianyu L, Kathy R, Gretchen L, Jennie S, Bartek R, Melendez JA, Robinson JP: DPI induces mitochondrial superoxide-mediated apoptosis. Free Rad Biol Med 2003, 34(4):465-477

37. Circu ML, Aw TY: Reactive oxygen species, cellular redox systems, and apoptosis. Free Rad Biol Med. 2010, 48:749-762.

38. Ding $X$, Fengxin Z, Tang L, Qiugen Z, Fan FH, Jing N: Numb protects renal proximal tubular cells from puromycin aminonucleoside-induced apoptosis through inhibiting Notch signaling pathway. Int J Biol Sci 2011, 7:269-278.

39. Ferk F, Wolfgang WH, Filipic M, Bichler J, Haslinger E, Misik M, Nersesyan A, Grasl Kraupp B, Bojana Zegura B, Knasmüller S: Xanthohumol, a prenylated flavonoid contained in beer, prevents the induction of preneoplastic lesions and DNA damage in liver and colon induced by the heterocyclic aromatic amine amino-3-methyl-imidazo[4,5-f]quinoline (IQ). Mut Res/ Fund Mol Mech Mut 2010, 691(1-2):17-22.

40. Jung HA, Jin SE, Choi RJ, Manh HT, Kim YS, Min BS, Son YK, Ahn BR, Kim BW, Sohn HS, Choi JS: Anti-Tumorigenic Activity of Sophoflavescenol against Lewis Lung Carcinoma in vitro and in vivo. Arch Pharm Res 2011, 34(12):2087-2099.

41. Manna SK, Bose JS, Gangan V, Raviprakash N, Navaneetha T, Raghavendra PB, Babajan B, Kumar CS, Jain SK: Novel Derivative of Benzofuran Induces Cell Death Mostly by G2/M Cell Cycle Arrest through p53-dependent Pathway but Partially by Inhibition of NF-KB*. J Biol Chem 2010, 285(29):22318-22327.

42. Bohnenstengel Fl, Steube KG, Meyer C, Quentmeier H, Nugroho BW, Proksch P: ${ }^{1} \mathrm{H}$-cyclopenta[b]benzofuran lignans from Aglaia species inhibit cell proliferation and alter cell cycle distribution in human monocytic leukemia cell lines. Z Naturforsch C 1999, 54:1075-1083.

\section{doi:10.1186/1472-6882-13-223}

Cite this article as: Pieme et al: Induction of mitochondrial dependent apoptosis and cell cycle arrest in human promyelocytic leukemia HL-60 cells by an extract from Dorstenia psilurus: a spice from Cameroon. BMC Complementary and Alternative Medicine 2013 13:223.

\section{Submit your next manuscript to BioMed Central and take full advantage of:}

- Convenient online submission

- Thorough peer review

- No space constraints or color figure charges

- Immediate publication on acceptance

- Inclusion in PubMed, CAS, Scopus and Google Scholar

- Research which is freely available for redistribution 